Acta Universitatis Wratislaviensis No 3798

PRAWO CCCXXIII

Wrocław 2017

DOI: $10.19195 / 0524-4544.323 .13$

\author{
JACEK MAZURKIEWICZ* \\ Uniwersytet Zielonogórski \\ e-mail: j.mazurkiewicz@wpa.uz.zgora.pl
}

JAN MAZURKIEWICZ

\title{
Dlaczego jest tak źle, jeśli jest tak dobrze... Krytycznie o niektórych przepisach polskiej ustawy transplantacyjnej
}

Polska ustawa transplantacyjna ${ }^{1}$ jest w polskim piśmiennictwie prawniczym uważana za dobrą, a nawet za bardzo dobrą. Jednak kolejki, szczególnie wśród oczekujących na narządy pochodzące od dawców zmarłych, są długie ${ }^{2}$. Ocze-

* Dr hab., prof. nadzw. Uniwersytetu Zielonogórskiego.

1 Ustawa z dnia 1 lipca 2005 r. o pobieraniu, przechowywaniu i przeszczepianiu komórek, tkanek i narządów (Dz.U. z 2017 r. poz. 1000; dalej: u.t.).

2 Zob. Tabela: Krajowa Lista Oczekujacych na Przeszczepienie (2013 r.), http://www.poltransplant.org.pl/statystyka 2013.html (dostęp: 11.11.2014). Zob. też PROGRAM WIELOLETNI NA LATA 2011-2020 „NARODOWY PROGRAM ROZWOJU MEDYCYNY TRANSPLANTACYJNEJ", stanowiący załącznik do Uchwały nr 164/2010 Rady Ministrów z dnia 12 października 2010 r. w sprawie ustanowienia programu wieloletniego na lata 2011-2020 pod nazwą „Narodowy Program Rozwoju Medycyny Transplantacyjnej”, s. 17-18, http://www.dobreprogramyzdrowotne. pl/uploaded/file/prawo/NPZ/transplant.pdf (dostęp: 11.11.2014), gdzie m.in. czytamy: „od 2006 roku obserwuje się wyraźne zmniejszenie liczby pobrań narządów od zmarłych. W 2007 roku doszło do poważnego zmniejszenia liczby zgłoszeń dawców i pobrań narządów. W 2007 roku narządy do przeszczepienia pobrano od 352 zmarłych dawców (w 2006 r. od 496, a w 2005 r. od 556). W 2007 roku w Polsce dokonano średnio 9,2 pobrania narządowe na 1 mln mieszkańców, co uplasowało Polskę na jednym z ostatnich miejsc wśród krajów członkowskich Unii Europejskiej [...]. Jak wskazują powyższe dane, w 2007 r. Polska zajmowała jedno z ostatnich miejsc w Unii Europejskiej, jeśli chodzi o dawstwo narządów. Od lat liderami tego rankingu są Kraje Płw. Iberyjskiego (Hiszpania, Portugalia), a także Belgia, Francja i Austria. Wśród nowo przyjętych państw członkowskich najwyższe miejsce zajmują Czechy, natomiast niższe niż w Polsce wskaźniki dawstwa w przeliczeniu na $1 \mathrm{mln}$ mieszkańców notują Rumunia, Bułgaria i Cypr. Sytuacja w Polsce uległa pewnej poprawie i w 2008 roku przeszczepiono narządy pobrane od 427 dawców, co jednakże od- 
kujący na przeszczep widzą przed sobą perspektywę co najmniej kilku, jeśli nie kilkunastu miesięcy, i nie wiedzą, czy dożyją ${ }^{3}$. Biuletyn Poltransplantu dotyczący roku 2012 podaje na stronie tytułowej, że oczekiwanie na przeszczepienie nerki trwa od momentu rozpoczęcia dializ do operacji 2 lata i 6 miesięcy, natomiast czas pomiędzy wpisaniem na Krajową Listę Oczekujących na Przeszczepienie a transplantacją wynosi ok. 10 miesięcy ${ }^{4}$. Dlaczego więc mimo tak dobrej ustawy coś najwyraźniej szwankuje? Odpowiedzi można szukać albo w praktyce, albo w ustawie transplantacyjnej - a być może tu i tu.

Zanim jednak przedstawimy nasze dociekania i uwagi krytyczne oraz sugestie możliwych rozwiązań, chcielibyśmy przybliżyć kilka znaczących, a nawet wymownych informacji.

W roku 2012 zmarło w Polsce niemalże 44 tys. osób mających 20-55 lat ${ }^{5}$, czyli w wieku najczęściej najlepszym do pobierania narządów ${ }^{6}$. Wcześniej, w roku 2011 - co pozwala przypuszczać, że podobnie było w latach późniejszych $12 \%$ wszystkich zgonów było następstwem chorób naczyń mózgowych, wypadków komunikacyjnych ${ }^{7}$ oraz samobójstw ${ }^{8}$, które to przyczyny śmierci również są „najodpowiedniejszymi” dla pobierania narządów. Jest to więc ponad 45 tys. potencjalnie najlepszych dawców ${ }^{9}$. A jednak w roku 2013 zmarłych dawców było jedynie 594, od których dokonano przeszczepienia ok. 1500 narządów $^{10}$. W latach

powiada zaledwie 11,2 przeszczepom/milion populacji. Pozwoliło to na wykonanie przeszczepień nerki u ponad 800 chorych. Nadal jednak jest to zbyt mało w stosunku do potrzeb", http://www. dobreprogramyzdrowotne.pl/uploaded/file/prawo/NPZ/transplant.pdf.

3 Zob. też J. Wałaszewski, D. Stryjecka-Rowińska, Dawcy narząów unaczynionych, [w:] Transplantologia kliniczna, red. W. Rowiński, J. Wałaszewski, L. Pączek, Warszawa 2004, s. 35.

${ }^{4} \mathrm{http}: / / w w w . p o l t r a n s p l a n t . o r g . p l / b i u l e t y n \_2013 . h t m l$ (dostęp: 11.11.2014).

5 Rocznik statystyczny Rzeczypospolitej Polskiej 2013, Warszawa 2014, s. 210.

${ }^{6}$ Wiek do 55 lat wskazują jako wiek dawcy idealnego J. Wałaszewski, D. Stryjecka-Rowińska, op. cit., s. 37.

7 „Dawca w szeregu wypadków bywa osobą przypadkową, przywiezioną najczęściej z wypadku” - J. Jaroszek, Zagadnienia prawne pobierania narzadów ludzkich do przeszczepów, „Problemy Praworządności” (dalej: PP) 1984, nr 1, s. 18. „W praktyce lekarskiej istnieje zasadne przekonanie, że do przeszczepów najbardziej odpowiednie są tkanki pobrane od osób, które zmarły śmiercią gwałtowną, stosunkowo młodych i względnie zdrowych przed śmiercią" - idem, Przeszczepy $w$ świetle prawa $w$ Polsce, Warszawa 1988, s. 27, zob. też s. 25.

8 Rocznik statystyczny..., s. 211.

9 Zob. J. Wałaszewski, D. Stryjecka-Rowińska, op. cit., s. 36.

10 Warto porównać te informacje z danymi Irańskiego Ministerstwa Zdrowia i Edukacji Medycznej dotyczącymi wszystkich (nie tylko ex mortuo) przeszczepów w Iranie - państwie liczącym w 2016 r. 79926270 mieszkańców, lecz od lat objętego niezwykle surowymi sankcjami także UE, w tym Polski, dotykającymi również, w dramatyczny, w istocie zbrodniczy, sposób ochrony zdrowia ludności Iranu. Mimo tego kraj ten zajmuje pierwsze miejsce w transplantacjach nerek na Bliskim Wschodzie i czwarte miejsce pod względem przeszczepiania narządów w świecie; zob. KQ/PR, Iran witnessing increase in organ donation, transplant, http://www.presstv.ir/detail/2014/04/09/357843/ iran-sees-rise-in-organ-donation/ (dostęp: 11.11.2014): „Annually, 2500 kidney transplants. 500 liver transplants. 80 heart transplant, 15-20 lung transplants, and 20 pancreatic transplants are carried out 
wcześniejszych Poltransplant zarejestrował nawet o 12 dawców mniej. Natomiast na Krajowej Liście Oczekujących na Przeszczepienie w roku 2013 figurowało ok. 1500 osób $^{11}$.

W latach 1996-2012 w centralnym rejestrze sprzeciwów zostało zgłoszonych 26416 sprzeciwów, odliczając wycofane. To daje średnio 1550 sprzeciwów rocznie, choć takie stawianie sprawy nie jest miarodajne, gdyż w roku 2012 zgłoszono 399 sprzeciwy, rok wcześniej — 396, natomiast w ,rekordowym” 1997 r. 14545 sprzeciwów $^{12}$. Biorąc pod uwagę, że w roku 2013 zmarło 384 tys. osób ${ }^{13}$, oraz zakładając, iż śmiertelność wśród osób zgłaszających sprzeciw jest podobna do tego w całym społeczeństwie, łatwo obliczyć, że spośród osób zgłaszających sprzeciw umarło wtedy najprawdopodobniej ok. 155 osób. Wyraźnie widać także, iż gdyby nawet wszyscy wyrażający sprzeciw w danym roku tracili w tym samym roku życie, to liczba zmarłych w wypadkach i w wyniku samobójstw przewyższałaby w takim roku wielokrotnie liczbę osób wyrażających sprzeciw tego roku. Równie oczywistym jest, że porównanie takie też nie jest miarodajne, gdyż nie każda osoba zgłaszająca sprzeciw w danym roku umiera. Wspomniana dysproporcja jeszcze się więc pogłębia. I nawet jeżeli przyjmiemy, że drugie tyle osób wyraża sprzeciw w innej formie niż zgłoszenie go w rejestrze, to wciąż zaskakujący jest niedobór dawców w Polsce ${ }^{14}$.

in Iran. Iran ranks first in kidney transplantation in the Middle East and fourth in organ transplantation in the world".

$11 \mathrm{http}: / /$ www.poltransplant.org.pl/statystyka_2013.html (dostęp: 11.11.2014).

12 P. Malanowski, J. Marcinkowska, Centralny Rejestr Sprzeciwów, „Biuletyn Informacyjny Poltransplant" 2013, nr 1, s. 38-40.

13 Rocznik statystyczny..., s. 210.

14 Zob. Dramatyczna sytuacja polskiej transplantologii, http://fakty.interia.pl/news-dramatyczna-sytuacja-polskiej-transplantologii,nId,818703 (dostęp: 11.11.2014); G. Kurczuk, Interpelacja nr 7829 do ministra zdrowia w sprawie sytuacji w polskiej transplantologii, http://orka2.sejm.gov. pl/IZ5.nsf/main/2DA00E69 (dostęp: 11.11.2014); J. Pinkas, Odpowiedź podsekretarza stanu w Ministerstwie Zdrowia $-z$ upoważnienia ministra - na interpelacje $n r 7829$ w sprawie sytuacji w polskiej transplantologii, http://orka2.sejm.gov.pl/IZ5.nsf/main/7179DF0C (dostęp: 11.11.2014); J. Krasoń, Interpelacja $\mathrm{nr} 8036$ do ministra zdrowia w sprawie trudnej sytuacji polskiej transplantologii, http://orka2.sejm.gov.pl/IZ5.nsf/main/66B9C6DC (dostęp: 11.11.2014); B. Piecha, Odpowiedź sekretarza stanu $w$ Ministerstwie Zdrowia $-z$ upoważnienia ministra - na interpelacje nr 8036 w sprawie trudnej sytuacji polskiej transplantologii, http://orka2.sejm.gov.pl/IZ5.nsf/main/ 37414359 (dostęp: 11.11.2014); Małopolska - rekordowo mało dawców organów, http://forum. gazeta.pl/forum/w,61,25256164,25266522,Re_Malopolska_rekordowo_malo_dawcow_organow. html (dostęp: 11.11.2014). O niezadowalającej liczbie zmarłych dawców narządów zob. M. Głyda, Przeszczepianie nerek, „Medyczna Wokanda” (dalej: MW) 2011, nr 3, s. 36. O globalnym od wielu lat niedoborze narządów do przeszczepów zob. J. Haberko, Kilka uwag o pobraniu tkanek, komórek i narządów ex mortuo od cudzoziemców, MW 2011, nr 3, s. 103. Warto przywołać też obserwację Anetty Breczko: „,[w:] pierwszym kwartale 2007 r. przeszczepiono w kraju 162 nerki i 14 serc. To odpowiednio o 58 i 9 mniej niż w identycznym okresie 2006 r. (najgorszym w całej dekadzie). W lutym i marcu 2007 r. z powodu braku dawców w Polsce zmarło 9 osób oczekujących na przeszczep wątroby. W 2007 r. z napływających z całego kraju do Poltransplantu comiesięcznych raportów 
Artykuł, który oddajemy dziś edytorom, poprzedzało wystąpienie — przed kilkoma laty - na konferencji ${ }^{15}$ zorganizowanej przede wszystkim przez medyków. Była ona, jak mawiają Rosjanie, praktyczno-naukowa, na szczęście nie „czysto” akademicka. Tak jak wtedy, zaczniemy zatem od najistotniejszych dla naszych rozważań, ale przede wszystkim nadzwyczaj doniosłych praktycznie regulacji ustawy transplantacyjnej, oczywistych dla osób interesujących się problematyką przeszczepów, lecz niekoniecznie znanych wszystkim naszym ówczesnym słuchaczom.

Są to przepisy znajdujące się w rozdziale 2 polskiej ustawy transplantacyjnej: art. 5-6 oraz 10, wszystkie dotyczące sprzeciwów na eksplantację ex mortuo.

Najpierw, by uniknąć jakichkolwiek przekłaman, wiernie je przytoczymy, a dopiero później postaramy się zwrócić uwagę na ich mankamenty oraz przedstawimy sugestie, a także propozycje koniecznych, naszym zdaniem, zmian.

Art. 5.1. Pobrania komórek, tkanek lub narządów ze zwłok ludzkich w celu ich przeszczepienia lub pobrania komórek lub tkanek w celu ich zastosowania u ludzi można dokonać, jeżeli osoba zmarła nie wyraziła za życia sprzeciwu.

2. W przypadku małoletniego lub innej osoby, która nie ma pełnej zdolności do czynności prawnych, sprzeciw może wyrazić za ich życia przedstawiciel ustawowy.

3. W przypadku małoletniego powyżej lat 16 sprzeciw może wyrazić również ten małoletni.

4. Przepisów ust. 1-3 nie stosuje się w przypadku pobierania komórek, tkanek i narządów w celu rozpoznania przyczyny zgonu i oceny w czasie sekcji zwłok postępowania leczniczego.

Art. 6.1. Sprzeciw wyraża się w formie:

1) wpisu w centralnym rejestrze sprzeciwów na pobranie komórek, tkanek i narządów ze zwłok ludzkich zaopatrzonego we własnoręczny podpis;

2) oświadczenia pisemnego;

3) oświadczenia ustnego złożonego w obecności co najmniej dwóch świadków, pisemnie przez nich potwierdzonego.

2. Przepisy ust. 1 stosuje się również do sprzeciwu wyrażanego przez przedstawiciela ustawowego.

3. Sprzeciw jednego przedstawiciela ustawowego lub osoby, o której mowa w art. 5 ust. 3, jest skuteczny w stosunku do pozostałych.

4. Sprzeciw może być cofnięty w każdym czasie w formach, o których mowa w ust. 1.

$[\ldots]$

Art. 10. Przed pobraniem komórek, tkanek lub narządów od osoby zmarłej lekarz lub osoba przez niego upoważniona:

1) zasięgają informacji, czy nie został zgłoszony sprzeciw w formie określonej w art. 6 ust. 1 pkt 1;

2) ustalają istnienie sprzeciwu wyrażonego w formach, o których mowa w art. 6 ust. 1 pkt 2 i 3 , na podstawie dostępnych informacji lub dokumentów.

wynika, że liczba transplantacji spadła o ponad 60\% (w niektórych szpitalach do zera). Kolejki oczekujących na nerkę, serce i wątrobę wydłużyły się" — eadem, Podmiotowość prawna człowieka $w$ warunkach postęu biotechnomedycznego, Białystok 2011, s. 375, przyp. 78.

15 III Forum Jakości i Bezpieczeństwa w Ochronie Zdrowia, „Jakość i ryzyko w procesach klinicznych - aspekty prawno-medyczne w wymiarze międzynarodowym”, konferencja naukowa, Uniwersytet Medyczny im. Piastów Śląskich we Wrocławiu, Wrocław 10-11 kwietnia 2014 r. 
Część unormowań zawartych w tych przepisach nie nastręcza w praktyce większych trudności. W szczególności odnosi się to do stwierdzenia, że chodzi w nich o sprzeciw wobec eksplantacji post mortem wyłącznie w celu przeszczepienia ${ }^{16}$. Nie budzi też doniosłych praktycznie kontrowersji konstatacja, że brak sprzeciwu wolno uznać za zgodę domniemaną ${ }^{17}$, co z troski o ratowanie ludzkiego

16 Zob. np. J. Haberko, [w:] J. Haberko, I. Uhrynowska-Tyszkiewicz, Ustawa o pobieraniu, przechowywaniu i przeszczepianiu komórek, tkanek i narządów. Komentarz, Warszawa 2014, s. 66 n. Zob. też E.M. Guzik-Makaruk, Transplantacja organów, tkanek i komórek w ujęciu prawnym i kryminologicznym. Studium prawnoporównawcze, Białystok 2008, s. 294-295; M. Nesterowicz, K. Śliwka, Pobieranie ze zwłok komórek, tkanek i narząów do celów naukowych - problem prawny i medyczny, „Prawo i Medycyna” (dalej: PiM) 2009, nr 4, s. 5-6; R. Kędziora, Odpowiedzialność karna lekarza w zwiazku z wykonywaniem czynności medycznych, Warszawa 2009, s. 361. Por. na gruncie poprzedniej ustawy transplantacyjnej M. Nesterowicz, Ochrona osobowości, prokreacja medycznie wspomagana i inżynieria genetyczna w prawie francuskim, [w:] Teoria prawa. Filozofia prawa. Wspótczesne prawo i prawoznawstwo. Profesorowi Wiestawowi Langowi w siedemdziesiata rocznice urodzin, Toruń 1998, s. 206. Por. też M. Żelichowski, Pobranie komórek, tkanek i narząów: zgoda jest reguła, sprzeciw wyjątkiem, „Rzeczpospolita” 2007, nr 224, dodatek „Prawo co dnia”, s. C7; A. Breczko, op. cit., s. 368. Warto przywołać również dramatyczną, lecz chyba przesadną obawę, że potrzeba zgody na pobranie komórek, tkanek i narządów ze zwłok do celów naukowych, diagnostycznych lub dydaktycznych ,oznacza koniec badań naukowych i postępu wiedzy” - M. Nesterowicz, K. Śliwka, op. cit., s. 6. Zob. też ibidem, s. 7 - propozycje de lege ferenda mające przeciwdziałać takim konsekwencjom, a także ibidem, s. 12 - wnioski.

17 Zob. E. Zielińska, Transplantacja w świetle prawa w Polsce i na świecie, „Państwo i Prawo" (dalej: PiP) 1995, z. 6, s. 25; M. Nesterowicz, Cywilnoprawne aspekty transplantacji komórek, tkanek i narzadów, PiM 1999, nr 3, s. 65-66; J. Duda, Transplantacja w prawie polskim. Aspekty karnoprawne, Kraków 2004, s. 61 n.; M. Świderska, Zgoda pacjenta na zabieg medyczny, Toruń 2007, s. 178-179, 338 n.; R. Kędziora, op. cit., s. 360-361; J. Duda, Cywilnoprawna problematyka transplantacji medycznej, Warszawa 2011, s. 86 n.; J. Haberko, Kilka uwag..., s. 102, 104; A. Breczko, op. cit., s. 363; D. Tykwińska-Rutkowska, Transplantacja. Studium z prawa administracyjnego, Warszawa 2013, s. 136 n. (ibidem, s. 137 - wskazane w przyp. 32 in fine dwie niedostępne we wrocławskich bibliotekach publikacje); A. Gałęska-Śliwka, Transplantacja ex mortuo z udziatem matoletniego, PiM 2013, nr 1-2, s. 76; О.А. Халабуденко, Правовойрежиморганов, тканей и клетокчеловекапослесмерти, [w:] Non omnis moriar. Osobiste i majątkowe aspekty prawne śmierci człowieka. Zagadnienia wybrane, red. J. Gołaczyński et al., Wrocław 2015, s. 335, 336-339; М.А. Капустина, Посмертноедонорство: проблемыправовогорегулирования, [w:] Non omnis moriar. Osobiste i majątkowe..., s. 401-404, 408-409, 415; K.M. Zoń, Sprzeciw na pobranie komórek, tkanek lub narząów post mortem w przypadku osób matoletnich, [w:] Non omnis moriar. Osobiste i majątkowe..., s. 923. Por. S. Poździoch, M. Gibiński, Prawa lekarza. Zarys problematyki, Warszawa 2012, s. 177. Zob. też art. 17, w szczególności zd. 2, Additional Protocol to the Convention on Human Rights and Biomedicine concerning Transplantation of Organs and Tissues of Human Origin, http://conventions.coe.int/Treaty/en/Treaties/Html/186.htm (dostęp: 11.11.2014); por. rządowe tłumaczenie na język polski: Protokół dodatkowy do Konwencji o Prawach Człowieka i Biomedycynie dotyczący transplantacji narządów i tkanek pochodzenia ludzkiego, http://bip.kprm. gov.pl/download/75/7511/uwagiMS2.pdf (dostęp: 11.11.2014); por. rezolucję nr (78) 29 Komitetu Ministrów Rady Europy z dnia 11 maja 1978 r. dotyczącą harmonizacji ustawodawstwa państw członkowskich związanego z pobieraniem i przeszczepianiem ludzkich tkanek i narządów, którą znamy z przywołań i do której jakiejkolwiek, nie tylko oryginalnej, wersji nie byliśmy w stanie dotrzeć na żadnej ze stron rzekomo nieocenionej skarbnicy www. Por. nieprzekonującą nas i naszym 
życia godne jest akceptacji, choć często jest to oczywistym interpretacyjnym nadużyciem ${ }^{18}$.

Nie powinno być także wątpliwości co do tego, że lekarz lub osoba przez niego upoważniona nie tylko nie ma obowiązku, ale nie ma też prawnej legitymacji (uprawnienia) do uzyskiwania zgody rodziny czy innych osób na eksplantację ex mortuo ${ }^{19}$.

Zrozumiałe wątpliwości budzi natomiast pytanie, czy nie istnieje obowiązek informowania tych osób o takim zamiarze, choć — z jednej strony — brak takiego obowiązku jest zgodny z zasadami przyjętymi w u.t. ${ }^{20}$, z drugiej jednak — częstokroć niemożliwy do przestrzegania, jeśli lekarz ma obowiązek ustalenia również tego, czy sprzeciw nie został wyrażony w innych formach niż zgłoszenie w centralnym rejestrze sprzeciwów ${ }^{21}$.

zdaniem nietyczną co do możliwych skutków sugestię Wojciecha Załuskiego, przeciwnika zasady domniemanej zgody, który uzasadnia swe stanowisko tym, iż wzbudza ona „,negatywną reakcję wobec pobierania narządów od zmarłych krewnych" - idem, Czy stuszna jest zasada domniemanej zgody na pobieranie narządów od pacjentów?, „Prawo i Więź” 2014, nr 3, s. 48. Zob. też np. R. Dubowski, Non omnis moriar. Pobranie narząów zmarlego do przeszczepu w prawie hiszpańskim na tle prawa polskiego, [w:] Non omnis moriar. Osobiste i majątkowe..., s. 193, przyp. 14.

18 Zob. np. A. Złotek, Odpowiedzialność karna lekarza transplantologa, „Czasopismo Prawa Karnego i Nauk Penalnych" (dalej: CPKiNP) 2010, z. 1, s. 8 n. Por. krytykę wskazanego polskiego rozwiązania przez P.G. Nowaka, Pobieranie narządów od zmartych. Ocena porównawcza polskiej regulacji braku sprzeciwu oraz Systemu Aktywnej Rejestracji Dawców, PiM 2015, nr 3, s. 140 n.

19 Zob. R. Kędziora, Odpowiedzialność karna lekarza w związku z wykonywaniem czynności medycznych, http://lex.online.wolterskluwer.pl/WKPLOnline/index.rpc?\&fromHistory=false\#content.rpc--ASK--nro $=151093665 \&$ wersja $=0 \&$ scrollTo $=$ na0 $\&$ class $=$ HTML $\& l o c=4 \&$ full $=1 \& \mathrm{hId}=5$ (dostęp: 11.11.2014); M. Nesterowicz, Prawo medyczne, Warszawa 2007, s. 294-295; J. Zajdel, Kompendium prawa medycznego, Łódź 2008, s. 84; M. Paszkowska, Cywilnoprawny aspekt transplantacji organów, http://www.zdrowie.abc.com.pl/czytaj/-/artykul/cywilnoprawny-aspekt-transplantacji -organow (dostęp: 11.11.2014); M. Nesterowicz, Prawo medyczne, Toruń 2010, s. 326-327. Można jeszcze dodać, że Teresa Gardocka najpierw stwierdza, że ,prawo nie wymaga zgody [...] osób [bliskich - J.M., J.M.] na pobranie ze zwłok ludzkich materiału do transplantacji”, a potem dodaje, że rozmowa „z tymi osobami powinna być wyłącznie formą interpersonalnego kontaktu, który ma wskazać na wartość tego, co mimo śmierci człowieka może uczynić jego pozostałe na ziemi ciało pożytecznym dla innych ludzi" - eadem, Zwłoki ludzkie w kontekście pobrania komórek, tkanek i narządów w celach transplantacyjnych i nie tylko, MW 2011, nr 3, s. 100. Por. M. Sośniak, Zagadnienia prawne przeszczepów, PiP 1971, z. 2, s. 227-228; idem, Cywilna odpowiedzialność lekarza, Warszawa 1989, s. 200-201, 203, 206; M. Nesterowicz, Ustawa o zaktadach opieki zdrowotnej, „Polski Tygodnik Lekarski” 1992, nr 29-30, s. 664; idem, Cywilnoprawne aspekty..., s. 66-68; J. Haberko, Prawne aspekty sekcji zwłok matoletniego, PiP 2010, z. 10, s. 97 n.; A. Breczko, op. cit., s. 363; R. Dubowski, op. cit., s. 195. Por. J. Bujny, Prawa pacjenta. Między autonomia a paternalizmem, Warszawa 2007, s. 169.

20 Zob. M. Nesterowicz, Prawo..., 2010, s. 326. Por. idem, Cywilnoprawne aspekty..., s. 66-68.

${ }^{21}$ Por. np. 1.p. 11 załącznika nr 1 RAMOWY PROGRAM SZKOLEŃ: WSTĘPNEGO, USTAWICZNEGO I UAKTUALNIAJĄCEGO, ORGANIZOWANYCH PRZEZ CENTRUM ORGANIZACYJNO-KOORDYNACYJNE DO SPRAW TRANSPLANTACJI „POLTRANSPLANT” - MINIMALNY CZAS SZKOLENIA 40 GODZIN do Rozporządzenia Ministra Zdrowia z dnia 30 marca 2010 r. w sprawie szkoleń osób, których czynności bezpośrednio wpływają na jakość 
Przeciwstawne są poglądy dotyczące tego, czy w odniesieniu do pacjenta przyjmowanego do szpitala uzasadnione jest informowanie go o możliwości wyrażenia sprzeciwu. Także ${ }^{22}$ dla nas oczywiste jest, że taki pomyst ${ }^{23}$ jest przede wszystkim nie do zaakceptowania ze względu na dobro pacjenta, a ponadto oczywiście - nieetyczny ${ }^{24}$.

Większych trudności de lege lata nie stwarza interpretacja unormowania ustawy dotyczącego wpisu sprzeciwu i jego cofania w centralnym rejestrze sprzeciwów (choć budzić mogą one wątpliwości i uzasadniać postulaty de lege ferenda, do czego nawiążemy) ani postępowań w tych przypadkach.

Inaczej ma się sprawa ze sprzeciwem w odmiennej formie. Pomijając inne kwestie szczegółowe, najdonioślejszą jest obserwacja, do której dalej również nawiążemy, że ustalanie przez lekarza lub osobę upoważnioną istnienia sprzeciwu w tej odmiennej formie wiąże się z niebezpieczeństwem „kreowania” dowodów, w szczególności przez osoby podające się za świadków, o których mowa w art. 6 ust. 1 pkt 3 u.t.

komórek, tkanek lub narządów, a także bezpieczeństwo dawców i biorców (Dz.U. Nr 64, poz. 403), gdzie jako tematykę zajęć wskazano rozmowę „,z rodziną zmarłego o pobraniu narządów”. Zob. też art. 17 pkt 12 Explanatory Report, http://conventions.coe.int/treaty/en/Reports/Html/186.htm (dostęp: 11.11.2014): ,[w] [watever the system, if the wishes of the deceased are not sufficiently established, the team in charge of the removal of organs must beforehand endeavour to obtain testimony from relatives of the deceased. Unless national law otherwise provides, such authorisation should not depend on the preferences of the close relatives themselves for or against organ and tissue donation. Close relatives should be asked only about the deceased persons expressed or presumed wishes. It is the expressed views of the potential donor which are paramount in deciding whether organs or tissue may be retrieved. Parties should make clear whether organ or tissue retrieval can take place if a deceased person's wishes are not known and cannot be ascertained from relatives or friends".

22 Już w 1992 r., na gruncie ustawy o zakładach opieki zdrowotnej, Mirosław Nesterowicz sformułował opinię, która nic nie straciła na znaczeniu: ,[u]stawa, która daleko chroni prawa pacjenta nie wprowadza obowiązku poinformowania go o możliwości zgłoszenia sprzeciwu co do pobrania po jego śmierci tkanek i narządów. Nie wyobrażam sobie innego rozwiązania. Informowanie o tym pacjenta w szpitalu, czy w chwili przyjęcia do szpitala nie wpłynie dobrze na jego stan psychiczny i na proces leczenia, stworzy obawę, że na jego zgon się czeka. Gdy natomiast pacjent zbliża się do śmierci, to taka informacja jest tym bardziej nie na miejscu" — idem, Ustawa o zakładach..., s. 664. Zob. też idem, Zaklady opieki zdrowotnej (system organizacyjny, obowiazki i odpowiedzialność cywilna), PiP 1994, z. 4, s. 54.

23 O tym, że brak obowiązku informowania przez lekarza osób przyjmowanych do szpitala lub przebywających w nim o możliwości wyrażenia sprzeciwu jest „sprzeczny z zasadą lojalności”, zob. S. Rutkowski, Wybrane zagadnienia z zakresu odpowiedzialności karnej lekarza, „Prokuratura i Prawo" 1999, nr 9, s. 83. Por. np. E. Zielińska, op. cit., s. 26; zob. też D. Tykwińska-Rutkowska, op. cit., s. 143, przyp. 58, gdzie przywołano niedostępną we wrocławskich bibliotekach publikację, oraz s. 145. Zob. też J. Haberko, [w:] J. Haberko, I. Uhrynowska-Tyszkiewicz, op. cit., s. 69-70.

${ }^{24}$ O tym, żeby wymagać od pacjenta przyjmowanego do hospitalizacji informacji dotyczącej możliwości eksplantacji post mortem, zob. też E.M. Guzik-Makaruk, op. cit., s. 296-297: „nasuwa się pewien postulat de lege ferenda, a mianowicie [...]”, aby nałożyć na „personel szpitalny” obowiązek „uzyskania pisemnej informacji od pacjenta przyjmowanego do hospitalizacji” dotyczący jego stanowiska „w zakresie transplantacji postmortalnej”. 
Wymóg ustalania istnienia sprzeciwu w innych formach niż wpis w centralnym rejestrze sprzeciwów ${ }^{25}$, o czym też będziemy szerzej pisać, stawia lekarza w roli śledczego ${ }^{26}$, który musi szukać i zbierać informacje, choć jego kompetencje formalne i kwalifikacje merytoryczne do takich poszukiwań są nieporównywalnie mniejsze niż policjanta, a nawet prywatnego detektywa. Lekarz jest w pożałowania godnym położeniu: częstokroć nie wie, gdzie szukać, jak stanowczo zabiegać o informacje w trakcie tych poszukiwań, jak oceniać wiarygodność dostarczanych mu dokumentów, nie tylko pod względem merytorycznym, lecz nawet formalnym. Szczególnie że musi brać także pod uwagę, doniosłą również post mortem, prywatność pacjenta i obowiązującą go dalej tajemnicę zawodową. Lekarz może też niekiedy obawiać się bolesnych dla siebie konsekwencji prawnych takiego stanu rzeczy. Dlatego uważamy, że ,ustalenie istnienia sprzeciwu", podobnie jak w punkcie wcześniejszym art. 10 u.t., powinno ograniczać się do obowiązku „zasięgnięcia informacji”. To pierwszy z naszych postulatów de lege ferenda.

Warto na to zagadnienie spojrzeć przede wszystkim z perspektywy obaw, które rodzi praktyka. Jak zauważa m.in. Anita Gałęska-Śliwka:

rodzi się pytanie, czy nie będzie dochodziło do patologii przy ustalaniu woli pacjenta. Czy przy aktualnym stanie prawnym możemy mieć $[\ldots]$ pewność, że np. członkowie rodziny negatywnie nastawieni do ewentualnego pobrania od ich bliskiego komórek, tkanek, narządów nie będą „preparowali” dokumentów, w których dwie osoby pisemnie będą potwierdzały fakt zgłoszonego przez zmarłego sprzeciwu? ${ }^{27}$

Z nadzwyczaj istotną, jeśli nie najdonioślejszą dla naszych rozważaniach kwestią wiąże się jednak obserwacja Teresy Gardockiej, która stwierdza, że mimo braku potrzeby uzyskiwania zgody rodziny $\mathrm{w}$,praktyce, w braku w rejestrze sprzeciwu, lekarze czynią starania, by uzyskać zgodę osób najbliższych na pobranie z ciała zmarłego komórek, tkanek lub narządów”, i pyta: „,[n]ależy sobie zadać [...] podstawowe pytanie, dlaczego tak czynią?”. Odpowiadając nań, zauważa, iż można

domyślać się, że lekarze obawiają się podejrzeń osób najbliższych o przedwczesne stwierdzenie, iż nastąpiła śmierć [...]. Uzyskanie zgody osób najbliższych na dokonanie pobrania usuwa w odczuciu lekarzy taką obawę. Jest to chyba jedyna obawa lekarzy, którą można zrozumieć — obawa oskarżenia o przedwczesne stwierdzenie śmierci, czyli o zaniechanie leczenia ${ }^{28}$.

25 Por. R. Dubowski, op. cit., s. 194, gdzie padło zadziwiające stwierdzenie, że żaden „przepis wprost nie nakłada na lekarza zamierzającego dokonać pobrania obowiązku ustalenia, czy zmarły wyraził swoją wolę w inny niż poprzez wpis w centralnym rejestrze sposób".

26 Zob. M. Świderska, op. cit., s. 342; zob. też J. Duda, Cywilnoprawna problematyka..., s. 94-95. Jak zauważa Joanna Haberko, obecny „kształt przepisu sugeruje »poszukiwanie« sprzeciwu, nawet jeżeli w istocie nie został złożony. Dotyczy to zwłaszcza sytuacji wskazanej w art. 6 ust. 1 pkt 3 u.p.p.p." — eadem, [w:] J. Haberko, I. Uhrynowska-Tyszkiewicz, op. cit., s. 107.

27 A. Gałęska-Śliwka, op. cit., s. 78.

28 T. Gardocka, op. cit., s. 98-99. Na tej ostatniej stronie autorka dodaje, że w przywołanym przez nas wcześniej „,dokumencie »Narodowy program rozwoju medycyny transplantacyjnej. Pro- 
Inna, choć związana z poprzednimi, obserwacja wskazuje, że

lekarze, mimo braku sprzeciwu osoby zmarłej, realizują swoją moralną potrzebę, zasięgają opinii osób najbliższych i w wyniku ich sprzeciwu nie decydują się na pobranie organów, czyniąc to niejako contra legem ${ }^{29}$.

Nie jest to praktyka „niejako contra legem”, lecz w oczywisty sposób sprzeczna z prawem i nadzwyczaj niemoralna, jej konsekwencją jest bowiem nierzadko śmierć osoby, która oczekuje na przeszczep. Wydaje się, że uzasadnia to dostatecznie dla wielu kontrowersyjną sugestię de lege ferenda, aby lekarz w wyniku swego poszukiwania sprzeciwu nie mógł poprzestać na pozorach takiego sprzeciwu, lecz musiałby oświadczyć, że sprzeciw istnieje, że jest wiarygodny, oraz załączyć go do dokumentacji medycznej. Można bowiem przypuszczać, że postawa lekarzy, o której wspomina autorka, jest konsekwencją nie tylko obaw przed konfliktem z rodziną zmarłego, lecz niekiedy także przejawem asekuranctwa, co samo w sobie, choć niemoralne, nie byłoby czymś aż tak karygodnym, gdyby od tego nie zależało niekiedy ludzkie życie.

Oczywista jest przy tym de lege lata konieczność uzyskiwania zgody, w szczególności rodziny, gdy chodzi o eksplantację ex mortuo ze zwłok zmarłego w Polsce cudzoziemca, jeśli jego prawo właściwe przewiduje obowiązek uzyskiwania takiej $\operatorname{zgody}^{30}$.

gram wieloletni na lata 2011-2020« [stanowiący załącznik do Uchwały nr 164/2010 Rady Ministrów z dnia 12 października 2010 r., s. 29, zob. eadem, op. cit., s. 99; zob. też przyp. 13 - J.M., J.M.] wśród przyczyn istnienia problemu zbyt małej w stosunku do potrzeb ilości materiału do przeszczepienia wymienia się jako pierwszą przyczynę opór społeczeństwa: »Nadal istniejące bariery obyczajowe $\mathrm{w}$ społeczeństwie związane $\mathrm{z}$ trzema wrażliwymi $\mathrm{w}$ odbiorze aspektami tej metody leczenia: rozpoznaniem zgonu człowieka w oparciu o kryteria śmierci mózgu, zgonu, wątpliwości dotyczące prawnego rozwiązania sposobu autoryzacji pobrania od zmarłego (zgoda wprost, zarejestrowany sprzeciw, zgoda rodziny). Ten pojawiający się okresami większy niepokój społeczeństwa nasilany jest przez różne wydarzenia medialno-prasowe«". Warto przytoczyć tu jednak intrygującą informację, iż w „tamtym [2016 - J.M., J.M.] roku CBOS przeprowadził badanie, z którego wynika, że 80 proc. dorosłych Polaków zgadza się, by po śmierci pobrano im narządy do przeszczepów. Co dziewiąty (11 proc.) jest temu przeciwny. Jednak 75 proc. nie rozmawiało z bliskimi na ten temat. W ocenie CBOS, niechęć do zostania dawcą narządów po śmierci częściej niż inni deklarują najstarsi respondenci, a także badani najsłabiej wykształceni, renciści oraz osoby najbardziej zaangażowane w praktyki religijne. Wyróżniają się pod tym względem również osoby źle sytuowane oraz bezrobotne" - M. Drozdek, Jej ojciec nie mógł pogodzić się z tym, że zmarła. Dostat wyjątkowy „prezent”, https://kobieta.wp.pl/jej-ojciec-nie-mogl-pogodzic-sie-z-tym-ze-zmarla-dostal-wyjatkowy-prezent-6135950813824641a (dostęp: 11.11.2014).

29 E.M. Guzik-Makaruk, op. cit., s. 335.

30 O szczególnych trudnościach z ustaleniem sprzeciwu w odniesieniu do zmarłych w Polsce cudzoziemców zob. J. Haberko, Kilka uwag..., s. 101 n.; eadem, [w:] J. Haberko, I. Uhrynowska-Tyszkiewicz, op. cit., s. 74-76. Dużo wcześniej, analizując protokół dodatkowy o transplantacji z 8 listopada 2001 r., Andrzej Rzepliński wskazywał m.in. na sytuacje, gdy po sprzeciwie złożonym w stosownym rejestrze osoba, która go złożyła, ,deklarowała wahania lub zmianę swojej postawy [...]”, gdy mimo niezłożenia takiego sprzeciwu deklarowała „niechęć wobec ewentualnego pobrania jej organów lub tkanek po śmierci [...]", albo w odniesieniu do zmarłego cudzoziemca, 
W odniesieniu do wszystkich możliwości eksplantacji post mortem ustawa nie wskazuje, kogo lekarz powinien zapytać o istnienie sprzeciwu w formie pisemnego oświadczenia lub pisemnego potwierdzenia świadków, którzy sprzeciw z ust zmarłego słyszeli. Czy takie pytanie należy kierować do rodziny, czy tylko do osoby najbliższej? Najczęściej właśnie do niej, gdyż wielokrotne zdarza się, że to ona ma także prawo do informacji o zdrowiu pacjenta. Jednak jeżeli pacjent po przywiezieniu do szpitala wskazał inną osobę, która ma zostać poinformowana o jego stanie zdrowia i ma mieć wgląd do dokumentacji medycznej, to pytanie powinno zostać skierowane przede wszystkim do tej osoby, a może nawet tylko do niej. Uważamy, że de lege ferenda ustawa powinna precyzyjnie określać, kogo lekarz bądź osoba przez niego upoważniona, zgodnie z art. 10 u.t., powinni o to pytać.

Wszyscy medycy wiedzą, inni co najmniej domyślają się, jak ważny jest czas, w którym narząd powinien zostać pobrany i sam przeszczep wykonany ${ }^{31}$. Jednak

gdy nie można szybko uzyskać informacji „, z bazy danych kraju pochodzenia albo baza taka w jego kraju nie jest jeszcze prowadzona”; podkreślał też, że wtedy „,[p]rotokół wymaga obowiązkowego przeprowadzenia postępowania określonego w prawie krajowym. Prawo to może nakazywać wówczas uzyskanie zgody osoby najbliższej, zgody osoby znajomej zmarłego, godnej zaufania publicznego, albo zezwolenia właściwego organu władzy niezależnego od personelu medycznego (art. 17.1). Przedmiotem takiego postępowania może być wyłącznie rozstrzygniecie o wyrażonej wprost lub w sposób dorozumiany woli osoby zmarłej co do ewentualnego sprzeciwu wobec pobrania organów lub tkanek na wypadek śmierci. W przypadku cudzoziemca w postępowaniu takim o rozstrzygnięciu powinno decydować prawo krajowe państwa pochodzenia" - idem, Prawne granice dopuszczalności transplantacji narządów i tkanek ludzkich w myśl przepisów Rady Europy, PiM 2002, nr 12, s. 60. Na marginesie: uważamy, że wspomniane prawo kraju pochodzenia powinno zostać zastąpione w niektórych sytuacjach prawem kraju zamieszkania. Por. 14 Dyrektywa Parlamentu Europejskiego i Rady 2010/53/UE z dnia 7 lipca 2010 r. w sprawie norm jakości i bezpieczeństwa narządów ludzkich przeznaczonych do przeszczepienia (Dz.Urz. UE PL z dnia 6 sierpnia 2010 r., L 207/14 ze sprost.): „Wymagania dotyczące zgody. Narządy pobiera się dopiero po spełnieniu wszystkich obowiązujących w danym państwie członkowskim wymogów dotyczących zgody, upoważnienia lub braku jakiegokolwiek sprzeciwu".

31 Zob. np. M. Kosieradzki, R. Danielewicz, Uszkodzenie niedokrwienne narządów i ich przechowywanie, [w:] Transplantologia kliniczna..., s. 107, tab. 7. Już w 1984 r. Jerzy Jaroszek pisał, że „nerka w odróżnieniu od innych tkanek zachowuje swą wartość biologiczną tylko w 30-60 minut po zgonie. Pobranie nerki po upływie tego czasu zmniejsza jej przydatność w transplantacji" — idem, op. cit., s. 18. Por. jednak np. pkt 2.5 lit. b załącznika II BADANIA LABORATORYJNE WYMAGANE W ODNIESIENIU DO DAWCÓW (Z WYJĄTKIEM DAWCÓW KOMÓREK ROZRODCZYCH), O KTÓRYCH MOWA W ART. 4 UST. 1 do dyrektywy Komisji 2006/17/WE z dnia 8 lutego 2006 r. wprowadzającej w życie dyrektywę 2004/23/WE Parlamentu Europejskiego i Rady w odniesieniu do niektórych wymagań technicznych dotyczących dawstwa, pobierania i badania tkanek i komórek ludzkich (Dz.Urz. UE PL z dnia 9 lutego 2006 r., L 38/40): ,[j]eżeli tkanki i komórki żywych dawców alogenicznych mogą być przechowywane przez długi czas, po upływie okresu 180 dni wymagane jest ponowne pobranie próbek i powtórne badanie. W tych okolicznościach powtórnego badania próbka donacyjna może być pobrana do 30 dni przed lub w ciągu 7 dni po pobraniu". Zob. też § 16 Rozporządzenia Ministra Zdrowia z dnia 29 września 2016 r. w sprawie szczegółowych warunków pobierania, przechowywania i przeszczepiania komórek, tkanek i narzą- 
sformułowanie zawarte w ustawie, przewidujące, że lekarz lub osoba przez niego upoważniona ustala ,istnienie sprzeciwu wyrażonego w formach, o których mowa w art. 6 ust. 1 pkt 2 i 3 [u.t.]", w żaden sposób nie ułatwia ich działań tak, aby trwały one jak najkrócej. Czy po zadaniu pytania osobie najbliższej o istnienie sprzeciwu należy pozostawić jej czas na odszukanie go? Wydawać by się mogło, że tak, jednak jest tego czasu najczęściej na tyle mało, że naszym zdaniem rozsądne byłoby, zgodnie zresztą z ustawą, w której znajduje się sformułowanie „na podstawie dostępnych [wyr. - J.M., J.M.] informacji lub dokumentów”, niepozostawianie tego czasu. Ponieważ szukanie dokumentu lub świadków, którzy przecież nie muszą wcale należeć do rodziny, może trwać dniami, tygodniami, miesiącami, teoretycznie nawet latami.

Tak więc jeżeli taki dokument albo pisemne potwierdzenie przez świadków nie są „,dostępne” w czasie koniecznym do eksplantacji i transplantacji, nie tylko wtedy, gdy nie ma pewności, czy w ogóle istnieją, lekarz lub osoba przez niego upoważniona powinni mieć prawo i naszym zdaniem mają obowiązek uznać, iż te formy sprzeciwu nie są dostępne, a więc, gdy chodzi o wymóg braku sprzeciwu, powinny przyjąć, że istnieje dopuszczalność pobrania komórek, tkanek lub narządów w celu przeszczepienia ${ }^{32}$.

Potrzebne jest, a nawet konieczne podjęcie również legislacyjnego trudu sformułowania takiej czy podobnej regulacji, do czego jeszcze nawiążemy, z której wynikałoby, że lekarz lub osoba przez niego upoważniona, która dopełniła opisanych przez nas starań, nie może być pociągana do odpowiedzialności za eksplantację mimo późniejszego ujawnienia sprzeciwu w jakiejkolwiek formie.

Przedstawione uwagi krytyczne biorą się oczywiście — o czym już wspominaliśmy — stąd, iż lekarz ma za zadanie ustalić ,,istnienie sprzeciwu wyrażonego w formach, o których mowa w art. 6 ust. 1 pkt 2 i 3, na podstawie dostępnych in-

dów (Dz.U. poz. 1674); § 14 uchylonego Rozporządzenia Ministra Zdrowia z dnia 4 grudnia 2009 r. w sprawie szczegółowych warunków pobierania, przechowywania i przeszczepiania komórek, tkanek i narządów (Dz.U. Nr 213, poz. 1656); 1.p. 7 załącznika nr 1 RAMOWY PROGRAM SZKOLEŃ: WSTĘPNEGO, USTAWICZNEGO I UAKTUALNIAJĄCEGO, ORGANIZOWANYCH PRZEZ CENTRUM ORGANIZACYJNO-KOORDYNACYJNE DO SPRAW TRANSPLANTACJI „POLTRANSPLANT” - MINIMALNY CZAS SZKOLENIA 40 GODZIN do Rozporządzenia Ministra Zdrowia z dnia 30 marca 2010 r. w sprawie szkoleń osób, których czynności bezpośrednio wpływają na jakość komórek, tkanek lub narządów, a także bezpieczeństwo dawców i biorców (Dz.U. Nr 64, poz. 403), gdzie jako tematykę zajęć wskazano: opiekę ,nad dawcą po rozpoznaniu śmierci mózgu. Wyrównywanie zaburzeń ustrojowych. Podtrzymywanie czynności narządów”.

32 Podzielamy opinię J. Haberko, że ,jeżeli członkowie rodziny czy osoby bliskie nie dysponują wiedzą o istnieniu sprzeciwu w trakcie pierwszej rozmowy z lekarzem lub osobą upoważnioną, ci ostatni nie powinni przyjmować dopuszczalności ustalania odpowiedniego terminu dla dalszego poszukiwania sprzeciwu przez członków rodziny czy osoby bliskie zmarłemu" - eadem, [w:] J. Haberko, I. Uhrynowska-Tyszkiewicz, op. cit., s. 107. 
formacji lub dokumentów"33, inaczej niż w przypadku sprawdzenia w centralnym rejestrze sprzeciwów, gdyż wtedy ma za zadanie tylko „zasięgnąć informacji”.

Oczywiste jest, do czego nawiązuje A. Gałęska-Śliwka, że lekarze muszą, przede wszystkim przy braku sprzeciwu zgłoszonego w rejestrze, szukać informacji o sprzeciwie poza nim. Teoretycznie powinni szukać wszędzie, gdzie takie informacje mogą być dostępne, co jest oczywiście równie absurdalne. Mają także obowiązek stwierdzenia, że sprzeciw wyrażony poza tym rejestrem jest wiarygodny, ponieważ został dokonany w sposób zgodny z prawem albo tak udowodniony i to w sytuacji, gdy ustawodawca większości dotyczących tego okoliczności nie określił. Co do sprzeciwu w formie ustnej w obecności świadków, którzy pisemnie to potwierdzili, to ta forma jest „w rezultacie czynnikiem neutralizującym zalety zgody domniemanej" ${ }^{34}$. Do tego też nawiązuje Joanna Haberko, konkludując, co równie oczywiste, że nie „należy [...] na lekarza nakładać obowiązków niemożliwych lub szczególnie trudnych do spełnienia"35.

Te i podobne obserwacje skłaniają autorkę do przywołanego już wyżej poglądu, że jeżeli

członkowie rodziny nie mają wiedzy o istnieniu sprzeciwu w trakcie ,pierwszej rozmowy” z lekarzem, nie powinien on przyjmować dopuszczalności ustalania odpowiedniego terminu w celu dalszego poszukiwania sprzeciwu przez członków rodziny czy osoby bliskiej zmarłemu. Moim zdaniem, nie należy podejmować działań, które dałyby rodzinie czas na „znalezienie” sprzeciwu czy ustalenia złożenia sprzeciwu wobec świadków. W razie gdy wola zmarłego i członków rodziny lub rzekomych świadków były rozbieżne, założenie dodatkowego czasu na „,znalezienie” dokumentów pozwalałoby im urzeczywistnić własne stanowisko, pomijając $\mathrm{w}$ tym zakresie rzeczywistą wolę zmarkego ${ }^{36}$.

\section{W innym miejscu autorka dodaje, że doświadczenie}

życiowe uczy, iż w takiej sytuacji rzeczywista wola zmarłego (objawiająca się niezłożeniem sprzeciwu) jest często wypaczana stanowiskiem ,świadków”, członków rodziny, którzy podejmują w tym zakresie decyzję o sprzeciwie, przyjmując na siebie funkcje rzekomych świadków oświadczenia zmarłego ${ }^{37}$.

33 Zob. J. Haberko, Prywatność pacjenta a sprzeciw na pobranie komórek, tkanek i narząów post mortem, PiP 2014, z. 3, s. 64. Por. eadem, [w:] J. Haberko, I. Uhrynowska-Tyszkiewicz, op. cit., s. 108, gdzie także zamieszczono uwagi, że lekarz powinien powstrzymać się od pobrania post mortem, nawet gdy dowiedział się od przyszłego zmarłego, że ten wyraża zgodę na eksplantację pośmiertną, jeśli dokumenty dostarczone przez bliskich lub zeznania świadków wskazują na odmienną wolę zmarłego. Nie znajdujemy żadnego uzasadnienia dla takiego stanowiska, oczywiście sprzecznego z ustawowym prawem do niewyrażenia sprzeciwu lub wyrażenia zgody na taką eksplantację.

34 A. Gałęska-Śliwka, op. cit., s. 77.

35 J. Haberko, Kilka uwag..., s. 105.

36 J. Haberko, Prywatność pacjenta..., s. 64, zob. też s. 63, 65. O wypaczeniu woli zmarłego przez ,świadków” zob. eadem, [w:] J. Haberko, I. Uhrynowska-Tyszkiewicz, op. cit., s. 109.

37 J. Haberko, Kilka uwag..., s. 104-105. Zob. też eadem, [w:] J. Haberko, I. Uhrynowska-Tyszkiewicz, op. cit., s. 79. Zespół do spraw opinii prawnych i regulacji międzynarodowych Krajowej Rady Transplantacyjnej 2014-2018 opublikował OPINIE w sprawie sposobów dokumentowania sprzeciwu dawcy za życia wyrażonego ustnie w obecności dwóch świadków w dokumentacji 
Konkludując, J. Haberko stwierdza,

że lekarz nie ma obowiązku podejmowania szczególnych i nadzwyczajnych działań służących ustaleniu istnienia sprzeciwu na pobranie tkanek, komórek i narządów w celu przeszczepienia w sytuacji, gdy nie został ujawniony sprzeciw w centralnym rejestrze sprzeciwów. Na podstawie przeprowadzonych analiz dopuszczalne jest założenie, że lekarz może podjąć próbę ustalenia istnienia sprzeciwu przez zapytanie członków rodziny lub osób bliskich ${ }^{38}$.

Naszym zdaniem istnieją teoretycznie przynajmniej trzy rozwiązania problemów, o których mówiliśmy na wspomnianej konferencji i piszemy w tej pracy.

Pierwsze z nich, nierealne, dotyczyłoby — wcześniejszej niż modyfikacja prawa — zmiany praktyki podczas ustalania istnienia innej formy sprzeciwu niż oświadczenie w centralnym rejestrze sprzeciwów. Mianowicie w sytuacji, w której osoba najbliższa, rodzina bądź osoba wskazana przez pacjenta nie potrafi w czasie umożliwiającym dokonanie eksplantacji w celu transplantacji udowodnić istnienia sprzeciwu, to z braku informacji należy przyjąć, że on nie istnieje. Takie rozwiązanie może wzbudzać kontrowersje, gdyż może powodować naruszenie woli zmarłego (w sytuacji gdy owo oświadczenie jednak istnieje), lecz zmarły, poza wyjątkowymi sytuacjami, nie jest przecież ante mortem pozbawiony możliwości wyrażenia sprzeciwu, brak zaś takiego sprzeciwu powinien umożliwiać ratowanie życia innego człowieka (in dubio pro vitae).

Druga propozycja de lege ferenda dotyczy ustawowego wymogu, że lekarz lub osoba przez niego upoważniona ustala istnienie sprzeciwu, który powinien zostać zastąpiony (tak jak de lege lata już jest w odnoszącym się do sprzeciwu zgłoszonego w rejestrze) określeniem, że lekarz lub osoba przez niego upo-

medycznej, autorstwa Romana Danielewicza, Ewy M. Guzik-Makaruk i Pawła Łukowa, w której stwierdzono m.in.: ,,[w] świetle doświadczenia życiowego jest trafna teza, iż domniemani świadkowie sprzeciwu przejmują na siebie rolę decydentów w zakresie ujawnienia woli zmarłego. Oznacza to, że wobec braku jakichkolwiek przesłanek formalnych oświadczenia złożonego wobec świadków, rzeczywista wola zmarłego (objawiająca się niezłożeniem sprzeciwu) może być wypaczana na podstawie twierdzeń »świadków « członków rodziny, którzy, choć nieuprawnieni, podejmują w tym zakresie decyzję o sprzeciwie. Należy w tym zakresie podzielić stanowisko, żeby de lege feren$d a$ świadkowie sporządzili dokument potwierdzający złożenie oświadczenia z opatrzeniem go datą i podpisami i by dokonano tego w chwili składania oświadczenia" — http://www.poltransplant.pl/ Download/OPINIA_w_sprawie_sposobow_dokumentowania_sprzeciwu_dawcy_za_zycia_wyrazonego_ustnie_w_obecnosci_dwoch_swiadkow_w_dokumentacji_medycznej.pdf, s. 2-3 (dostęp: 18.08.2017).

38 J. Haberko, Prywatność pacjenta..., s. 68, tam sugestia: ,[d]e lege ferenda można postulować, by pacjent wyrażał wobec braku akceptacji dla dorozumianej zgody na pobranie tkanek, komórek i narządów post mortem sprzeciw w formie pisemnej i by był on każdorazowo zamieszczany lub dołączany do dokumentacji medycznej”, czego (gdyby nie miało być tak, jak już jest, de lege lata możliwe, nieoświadczenie, będące przejawem samodzielnej inicjatywy pacjenta, lecz proponowane przez personel medyczny) nie akceptujemy z powodów przywołanych w niniejszym artykule. Por. też np. K.M. Zoń, op. cit., s. 925. 
ważniona zasięga informacji co do istnienia sprzeciwu w innej formie niż wpisanego w centralnym rejestrze sprzeciwów. Nie ciążyłby wtedy na nich obowiązek poszukiwania pisemnych dokumentów.

Trzecie rozwiązanie, najbardziej kontrowersyjne, miałoby na celu wyeliminowanie innych form sprzeciwu niż zapis w centralnym rejestrze sprzeciwów, z przedstawionym niżej wyjątkiem. Oczywiście powinno być to poprzedzone szeroką, ogólnopolską, medialną akcją informacyjną, uświadamiającą społeczeństwu, iż inne formy wyrażania sprzeciwu, poza jednym wyjątkiem, nie będą doniosłe prawnie. Wydaje się, że jest to droga trudniejsza, ale najlepsza z punktu widzenia potrzeb transplantologii. Wspomnianym wyjątkiem od tego rozwiązania byłaby sytuacja wyrażenia sprzeciwu przez hospitalizowanego pacjenta w obecności dwóch świadków, który natychmiast powinien być uwidoczniony w jego dokumentacji medycznej. Sprzeciw wyrażony w ten sposób traciłby ważność po zaprzestaniu hospitalizacji, o ile pacjent został poinformowany i miał możliwość zgłoszenia sprzeciwu w centralnym rejestrze sprzeciwów.

Konieczne jest także ponowne zwrócenie uwagi na jeszcze jedno zagadnienie — wadliwy kształt prawa, które wręcz prowokuje lekarzy lub osoby przez nich upoważnione do postaw powściągliwych, przesadnie ostrożnych, niekoniecznie asekuranckich. Obawiając się oceny swego postępowania, nierzadko, a może nawet często, pytają oni, jak już wiemy, bliskich zmarłego nie tylko o ewentualny jego sprzeciw, lecz tak formułują swoje pytanie, że budzą niekiedy u bliskich zmarłego przeświadczenie, że to oni mogą taki sprzeciw wyrazić ${ }^{39}$. Stąd nasza wcześniej wspomniana propozycja przepisu, który expressis verbis stwierdzałby, że lekarz, który zasięgnął informacji o sprzeciwie u osób, do których mógł dotrzeć bez nadzwyczajnych starań i bez uzasadnionej obawy wydłużenia czasu do eksplantacji, tak by nie była ona z punktu widzenia wymogów transplantacji możliwa, nie ponosi jakiejkolwiek odpowiedzialności (karnej, cywilnej, dyscyplinarnej) za to, że istnienie sprzeciwu zostało ustalone po dokonaniu eksplantacji. Byłby to chyba jedyny skuteczny instrument eliminujący prozaiczne, ale przecież doniosłe obawy — nie tylko lekarzy —

39 Kwestia osobno rozważana w piśmiennictwie to krąg osób, do których lekarz lub osoba przez niego upoważniona powinna się zwracać w celu ustalenia istnienia sprzeciwu. Na przykład T. Gardocka (op. cit., s. 99) wskazuje tu te osoby, które za uprawnione do pochowania wymieniono w art. 10 Ustawy z dnia 31 stycznia 1959 r. o cmentarzach i chowaniu zmarłych (Dz.U. z 2017 r. poz. 912), co jest oczywiście absurdem, zważywszy, że do kręgu tych osób zaliczono tam, poza np. wszystkimi zstępnymi (niekiedy mogą być to prawnuki) oraz krewnymi bocznymi do 4 . stopnia pokrewieństwa, nawet organy wojskowe, państwowe, instytucje i organizacje społeczne, a w zdaniu ostatnim każdą, także obcą zmarłemu, osobę (zob. też wcześniejsze uwagi autorki na s. 98, jakoby ante mortem nie można decydować o prawie do pochowania, zupełnie błędne). Por. J. Mazurkiewicz, Non omnis moriar. Ochrona dóbr osobistych zmarłego w prawie polskim, Wrocław 2010, s. 602 n., 611 n. 
przed konsekwencjami dopuszczenia do dokonania eksplantacji mimo istnienia nieznanego im sprzeciwu.

Do takich obaw nawiązuje odpowiedź znajdująca się na stronie Poltransplantu, dostępna w zakładce „Pytania i Odpowiedzi”. Odpowiadając na pytanie: „c zy lekarze powinni skontaktować się z rodziną przed pobraniem narzą dów?", wyjaśniono, że:

Według polskiego prawa każda osoba zmarła może być uważana za potencjalnego dawcę tkanek i narządów, jeśli za życia nie wyraziła sprzeciwu. Lekarze, pod opieką których był zmarły, informują zwykle rodzinę o śmierci i zamiarze pobrania narządów do przeszczepienia, lekarze pytają rodzinę, czy zmarły za życia nie wyraził sprzeciwu ustnie w obecności świadków, lekarze nie muszą prosić rodziny o wyrażenie zgody na pobranie narządów. Jeśli zmarły pozostawił pisemny zapis dotyczący jego woli odnośnie pobrania narządów (np. oświadczenie woli) po śmierci, lekarze respektują jego decyzję. Bliscy mogą jedynie potwierdzić opinię zmarłego na temat pobrania narządów, jeśli ją znają ${ }^{40}$,

udzielając rzetelnych i zgodnych z prawdą informacji.

W zamieszczonej na tej samej stronie odpowiedzi na pytanie: dlaczego w Polsce brakuje narządów do przeszczepiania?, czytamy jednak, iż wiedza

społeczeństwa o tym, jaką wartość dla setek śmiertelnie chorych ma przeszczepienie narządu, jest nadal niewystarczająca. Sprzeciw na pobranie narządu wyrażany przez rodzinę zmarlego powoduje, że nie można uratować życia wielu chorym. Należy prowadzić stałą kampanię edukacyjną, informującą o potrzebach i wynikach przeszczepiania narządów, która pomoże przekonać społeczeństwo o skuteczności tej metody leczenia ${ }^{41}$.

Jak widać, na jednej, wszak nie prywatnej i z punktu widzenia wiarygodności najdonioślejszej, stronie internetowej znajdują się: zgodna z ustawą i przeciwna jej, niezgodna z ustawą, informacja. Czy piszący ten tekst nie znał ustawy? Jest to nieprawdopodobne, i to nie dlatego, że wcześniej podaje informacje z nią zgodne, a w innych miejscach je cytuje ${ }^{42}$. Lecz mimo to, podobnie jak część lekarzy, najpierw stwierdza, że rodzina zgodnie z ustawą nie ma prawa decydowania, a potem pozwala sobie na sugestię, że wola rodziny, a nie zmarłego, jest tutaj doniosła prawnie $^{43}$.

$40 \mathrm{http}: / /$ www.poltransplant.org.pl/QA.html\#Czy_lekarze_powinni_skontaktowac_sie_z_rodzina (dostęp: 11.11.2014).

$41 \mathrm{http} / / /$ www.poltransplant.org.pl/QA.html\#Dlaczego_w_Polsce_brakuje_narzadow_do_ przeszcze (dostęp: 11.11.2014).

$42 \mathrm{http} / / /$ www.poltransplant.org.pl/QA.html\#Czy_biorca_moze_poznac_dowiedziec oraz http://www.poltransplant.org.pl/QA.html\#Jakie_przepisy_karne_zapisano_w_Ustawie_Transpl (dostęp: 11.11.2014).

${ }^{43} \mathrm{Na}$ tej samej stronie możemy także przeczytać, iż moc „prawną ma również noszone przy sobie własnoręcznie podpisane oświadczenie sprzeciwu lub oświadczenie ustne złożone w obecności dwóch świadków" — http://www.poltransplant.org.pl/QA.html\#Jak_zakomunikowac_wole_o_ sprzeciwie_lub_zgodzie (dostęp: 11.11.2014). I tu kolejna niedokładność, a nawet błąd, gdyż ustawa w żadnym razie nie precyzuje, iż oświadczenie pisemne należy nosić przy sobie. Oczywiście, przy ewentualnej potrzebie pobrania narządu, a więc konieczności ustalenia istnienia sprzeciwu w tej formie, byłoby to ułatwienie, jednak wydaje się nam, że jednostka, którą jest Poltransplant, 
W ustawie transplantacyjnej na zmiany czekają też inne postanowienia, nie tak doniosłe, jak wskazane wyżej. Wspomnijmy o nich pokrótce.

$\mathrm{W}$ piśmiennictwie prawniczym wielokrotnie zwracano uwagę na potrzebę rozważenia możliwości formułowania sprzeciwu, który dotyczyć będzie np. określonych narządów, podkreślano przy tym, że brak takiej możliwości zasługuje na krytykę $^{44}$, choć nie precyzowano argumentów, które miałyby to stanowisko uzasadniać. Dla zasadniczej idei transplantacji bez znaczenia jest jednak to, czym się mogą kierować ci, którzy chcą dopuścić eksplantację post mortem tylko niektórych komórek, tkanek i narządów. Jeżeli bowiem, dopuszczając możliwość sprzeciwu ograniczonego, uzyska się możliwość eksplantacji jakiegokolwiek narządu, tkanki czy komórki, należy uczynić wszystko, aby było to możliwe. Dzisiaj zaś, zdaniem m.in. J. Haberko, sprzeciw ma „,charakter totalny. Nie można de lege lata wyrazić go zatem co do pobrania wybranych narządów, tkanek lub komórek"45.

Naszym zdaniem art. 5 ust. 1 i art. 6 ust. 1 u.t., choć nie przewidują expressis verbis sprzeciwu ograniczonego, nie wykluczają możliwości objęcia sprzeciwem tylko np. określonych organów ${ }^{46}$. Inna sprawa, że formularz opublikowany przez Poltransplant ${ }^{47}$ takiej możliwości nie przewiduje, co zdaje się potwierdzać stanowisko o niedopuszczalności sprzeciwu ograniczonego. Można za Rafałem Kubiakiem zwrócić uwagę, że z „treści formularza wynika jednak, iż można wskazać rodzaj materiału, jakiego będzie dotyczył sprzeciw: komórki, tkanki czy narządu"48. Formularz zgłoszenia sprzeciwu rozpoczyna się bowiem zdaniem: „,[w]noszę o wpis w Centralnym Rejestrze Sprzeciwów, iż wyrażam sprzeciw na pobranie po śmierci komórek, tkanek i narządów*”, a odnośnik do * stwierdza „niepotrzebne skreślić”, z czego ponoć wynika, że sprzeciw może dotyczyć komórek, tkanek i narządów albo tylko komórek, tylko komórek i tkanek, tylko komórek i narządów, tylko tkanek, albo tylko tkanek i narządów. Odpowiednio dotyczy to zdania drugiego formularza, które stwierdza: „,[w]noszę o skreślenie wpisu sprzeciwu w Centralnym Rejestrze Sprzeciwów na pobranie po śmierci komórek, tkanek

powinna informować rzetelnie, tak aby osoba szukająca informacji nie musiała raz ustalonych dodatkowo weryfikować.

44 „Szkoda [...], iż nie przewidziano możliwości zawężenia swojej deklaracji jedynie do określonych narządów" - R. Kubiak, Prawo medyczne, Warszawa 2010, s. 488.

45 J. Haberko, [w:] J. Haberko, I. Uhrynowska-Tyszkiewicz, op. cit., s. 77. O tym, że nie przewidziano możliwości ,wyłączenia tylko niektórych narządów spod eksplantacji ex mortuo”, zob. J. Duda, Cywilnoprawna problematyka ..., s. 88. Por. np. R. Dubowski, op. cit., s. 195-196.

46 Na gruncie poprzedniej ustawy transplantacyjnej Stanisław Rutkowski wskazywał w odniesieniu do eksplantacji ex mortuo, że dawca może „oddać do dyspozycji wszystkie swoje narządy lub może godzić się na pobranie tylko niektórych narządów" - idem, op. cit., s. 82. Tak też D. Tykwińska-Rutkowska, op. cit., s. 138.

$47 \mathrm{http}: / /$ www.poltransplant.org.pl/crs1.html (dostęp: 11.11.2014).

48 R. Kubiak, op. cit., s. 488, przyp. 50. 
i narządów*"49. Naszym zdaniem stanowisko R. Kubiaka nie jest uzasadnione, ponieważ ten sam formularz dotyczy zarówno zgłoszenia wyrażenia sprzeciwu, jak i zgłoszenia skreślenia wpisu sprzeciwu, a oznaczenie * i odnośnik „niepotrzebne skreślić" ma na celu wybór tego, czego formularz ma dotyczyć: zgłoszenia wyrażenia sprzeciwu albo zgłoszenia skreślenia jego wpisu. Inna sprawa, że oznaczenie * i wskazany odnośnik mają prawo wprowadzać w błąd.

Jakie są merytoryczne argumenty, dla których osoba zgłaszająca sprzeciw nie mogłaby go ograniczyć np. do serca? Nie widzimy powodu, aby taką decyzję oceniać etycznie, zarzucając zainteresowanym losem swego serca po śmierci małostkowość, jeśli dzięki temu można uratować innemu życie, dokonując eksplantacji nerek czy trzustki tego samego zmarłego. Każdą taką ewentualność, nienaruszającą woli zmarłego, trzeba wykorzystać, a nie stawiać mu wymagań, które są do spełnienia przez przytłaczającą większość tych, którzy godzą się na pośmiertne pobranie bez ograniczeń.

Chcemy również nawiązać do innego postanowienia, zawartego w art. 5 ust. 3 u.t., zgodnie z którym „,w przypadku małoletniego powyżej lat 16 sprzeciw może wyrazić również ten małoletni”. Joanna Haberko wskazuje tutaj na wątpliwości i pyta: „czy wystarczy sprzeciw małoletniego, który ukończył wskazany wiek, czy potrzeba kumulatywnego sprzeciwu przedstawiciela ustawowego i małoletniego? Ustawodawca posłużył się” bowiem „sformułowaniem, że sprzeciw może wyrazić również [...] małoletni”, ale przychyla się ona do, także naszym zdaniem, poprawnej interpretacji, że sprzeciw samego małoletniego jest tak samo doniosły jak sprzeciw pełnoletniego ${ }^{50}$. Nieco dalej autorka formułuje też wątpliwości co do samej zasadności przyznania nawet małoletniemu, który ukończył 16 lat, w każdej sytuacji (np. „na zasadzie »nie, bo nie«, dla dokuczenia rodzicom czy z powodów zupełnie irracjonalnych") prawa do samodzielnego wyrażenia sprzeciwu $^{51}$. Nie podzielamy tych wątpliwości. Również brak uprawnienia do zgłoszenia sprzeciwu przez małoletniego, który nie ukończył 16 lat, uważamy za niemoralny, a ponadto sprzeczny z art. 72 ust. 3 Konstytucji RP ${ }^{52}$.

49 Inna sprawa, że w świetle $\S 2$ pkt 4 Rozporządzenia Ministra Zdrowia z dnia 1 grudnia 2006 r. w sprawie sposobu prowadzenia centralnego rejestru sprzeciwów oraz sposobu ustalania istnienia wpisu w tym rejestrze (Dz.U. Nr 228, poz. 1671), tylko jeżeli „zakres danych w nadesłanym zgłoszeniu jest niezgodny z art. 7 ust. 3 lub ust. 4 ustawy, Poltransplant odsyła zgłoszenie do osoby, o której mowa w art. 5 ust. 1-3 ustawy, bez dokonania wpisu w centralnym rejestrze sprzeciwów z jednoczesnym wskazaniem braków uniemożliwiających dokonanie wpisu" (zob. też § 4 pkt 3 tego rozporządzenia, który nakazuje $\S 2$ ust. 4 stosować odpowiednio do wykreślenia sprzeciwu w centralnym rejestrze sprzeciwów). Z czego można byłoby wyciągnąć usprawiedliwiony de iure, lecz chyba niezamierzony przez prawodawcę wniosek, że zgłoszenie sprzeciwu ograniczonego do np. wskazanych narządów nie uzasadnia niedokonania stosownego wpisu.

50 Zob. J. Haberko, [w:] J. Haberko, I. Uhrynowska-Tyszkiewicz, op. cit., s. 72.

51 Ibidem, s. 73.

52 Stanowi on, że w „toku ustalania praw dziecka organy władzy publicznej oraz osoby odpowiedzialne za dziecko są obowiązane do wysłuchania i w miarę możliwości uwzględnienia zdania dziecka”. Por. też np. K.M. Zoń, op. cit., s. 933, 937, także s. 929. 
Warto też zatrzymać się przy innej kwestii szczegółowej. Nietrudno bowiem zrozumieć motywy, dla których nieco inaczej traktuje się reżim uzyskiwania zgody na pobranie komórek, tkanek lub narządów od żywego dawcy na rzecz osoby będącej jej małoletnią córką albo synem niż zgody na pobranie komórek, tkanek lub narządów od żywego dawcy będącego małoletnim przysposobionym na rzecz osoby, która przysposobiła tego dawcę. W tym ostatnim przypadku wymagana jest zgoda sądu wskazanego w art. 13 ust. 1 u.t., które to rozwiązanie ma jednak prawo dziwić $\mathrm{w}$ odniesieniu do przysposobionej osoby, która w momencie zamiaru eksplantacji uzyskała już pełnoletność. Podobne, lecz także donioślejsze zastrzeżenia budzi postanowienie zawarte $\mathrm{w}$ art. 12 ust. 1 pkt 1 u.t., w którym dopuszcza się pobieranie od żywego dawcy w celu przeszczepienia innej osobie komórek, tkanek lub narządów, jeśli pobranie ich następuje m.in. na rzecz krewnego w linii prostej (czyli również na rzecz matki albo ojca), lecz w odniesieniu do stosunku przysposobienia tylko (w zasadzie, zob. art. 12 ust. 1 pkt 1 in fine u.t.) na rzecz osoby przysposobionej, nie zaś na rzecz osoby, która przysposobiła, i to także wtedy, gdy osoba przysposobiona jest już pełnoletnia. Podobne zastrzeżenia budzi wynikająca z przywołanego przepisu niemożliwość pobrania na rzecz osoby, która jest przysposobiona, od innej osoby przysposobionej przez tego samego przysposabiającego, gdy takiej bariery nie ma w odniesieniu do rodzeństwa.

Naszym zdaniem za długą może się niekiedy — może nawet często — okazać procedura mająca na celu ustalenie istnienia sprzeciwu w centralnym rejestrze sprzeciwów. Zgodnie bowiem z czterema ustępami § 6 Rozporządzenia Ministra Zdrowia z dnia 1 grudnia $2006 \mathrm{r}$. w sprawie sposobu prowadzenia centralnego rejestru sprzeciwów oraz sposobu ustalania istnienia wpisu w tym rejestrze ${ }^{53}$ istnienie „wpisu sprzeciwu w centralnym rejestrze sprzeciwów lekarz zamierzający dokonać pobrania lub osoba przez niego upoważniona ustala telefonicznie, faksem lub pocztą elektroniczną” (ust. 1), natomiast osoba, „o której mowa w ust. 1, potwierdza istnienie wpisu sprzeciwu w centralnym rejestrze sprzeciwów poprzez wysłanie do Poltransplantu przesyłką poleconą pytania zawierającego dane wymienione w art. 7 ust. 3 lub ust. 4 ustawy [...]” transplantacyjnej ,oraz następujące dane osoby wymienionej w art. 7 ust. $6[\ldots]$ " tej ustawy: ,1) imię i nazwisko; 2) numer i seria dowodu tożsamości; 3) numer PESEL; 4) adres podmiotu, w którym jest zatrudniona ta osoba” (ust. 2). Z kolei odpowiedź „na pytanie, o którym mowa w ust. 1, potwierdza się niezwłocznie zawiadomieniem o istnieniu lub braku wpisu sprzeciwu w centralnym rejestrze sprzeciwów" (ust. 3), lecz odpowiedź „na pytanie, o którym mowa w ust. 2, przesyła się w formie wydruku komputerowego potwierdzonego podpisem dyrektora Poltransplantu przesyłką poleconą" (ust. 4) $)^{54}$.

53 Dz.U. Nr 228, poz. 1671.

54 Zob. też R. Kubiak, op. cit., s. 489. 
Ocenić to unormowanie powinni przed wszystkim transplantolodzy, lecz nawet dla nas nieoczywiste jest wymaganie potwierdzania tych informacji w drodze przesyłania przesyłek poleconych, które chyba nie zapewniają, albo przynajmniej nie zawsze zapewniają, otrzymanie dokumentu w odpowiednim czasie i nie zawsze dają pewność, że dokument do adresata w ogóle dotrze.

Słuszne były więc, nieuwzględnione jednak, uwagi Jana Lipskiego, który opiniując rządowy projekt u.t., pisał:

Rozważenia wymaga uzupełnienie katalogu form uzyskiwania informacji [...] o tym, czy sprzeciw danej osoby umieszczony jest w centralnym rejestrze sprzeciwów [...], o rejestrowane rozmowy telefoniczne, które są niewątpliwie najszybszym sposobem komunikacji. Uwagę tę (w zakresie rejestrowania rozmów) można odnieść również do trybu uzyskiwania informacji lub stanowiska o których mowa w art. 8 (projekt rozporządzenia wydanego na podstawie art. 8 us. 2 przewiduje uzyskanie informacji na drodze telefonicznej, jednak bez zapewnienia utrwalenia rozmowy dla celów dowodowych) $)^{55}$.

Zresztą, jak zauważa J. Haberko, nawet obowiązujące dziś, przytoczone przez nas wyżej, przepisy rozporządzenia nie są jasne, i dodaje:

W tym zakresie pojawia się [...] pytanie, czy lekarz lub osoba przez niego upoważniona może poprzestać na ustaleniach dokonanych z wykorzystaniem środków porozumiewania się na odległość, czy też powinien poczekać do chwili otrzymania przesyłki poleconej zawierającej zawiadomienie o istnieniu lub braku wpisu sprzeciwu w centralnym rejestrze sprzeciwów ${ }^{56}$.

W dyskusji wokół transplantacji niemało było rozważań o charakterze moralnym $^{57}$. Nie podważając doniosłości poruszanych kwestii, chyba szczątkową była jednak zaduma nad tymi wadami prawa transplantacyjnego, które w praktyce nierzadko idee transplantacji obracają w niwecz, nic że w jednostkowych przypadkach, jeżeli dotyczą one ludzkiego życia.

$$
* * *
$$

Nawet naukowe oficyny wydawnicze o światowym zasięgu uszanowały autorskie prawo osobiste starszego, blisko siedemdziesięcioletniego współautora tego

55 J. Lipski, Opinia prawna na temat rządowego projektu ustawy o pobieraniu, przechowywaniu i przeszczepianiu komórek, narządów i tkanek (druk nr 3856), http://orka.sejm.gov.pl/rexdomk4. nsf/Opwsdr?OpenForm\&3856 (dostęp: 11.11.2014).

56 J. Haberko, [w:] J. Haberko, I. Uhrynowska-Tyszkiewicz, op. cit., s. 89, zob. też s. 88.

57 Zob. np. niewątpliwie ważkie zagadnienia poruszone w artykule B. Dobrowolskiej i J. Klukowa, Moralne kontrowersje wokót idei komercjalizacji transplantacji-opinie lekarzy i pielęgniarek regionu lubelskiego, [w:] Bioetyka w zawodzie lekarza, red. W. Chańska, J. Hartman, Warszawa 2010, s. 181 n. Por. marginalia pseudoetyczne u J. Hartmana, Bioetyka dla lekarzy, Warszawa 2012, s. 123; zob. też T. Stępień, Wybrane problemy prawno-medyczne ze szczególnym uwzględnieniem transplantacji, Toruń 2013, s. 11-12. 
artykułu, do wątków o charakterze osobistym, niedotyczących jego samego, choć bezsprzecznie związanych z szeroko rozumianą kwestią losu nie tylko pacjenta.

Mówiłem o tym podczas wspomnianej konferencji i teraz muszę powtórzyć krótkie, mądre opowieści z życia Jerzego Falenciaka — profesora Uniwersytetu Wrocławskiego, kanonisty i romanisty, mego Vater imago.

$* * *$

Było to chyba na początku lat sześćdziesiątych. Profesor przewodniczył wrocławskiemu oddziałowi Towarzystwa Wiedzy Powszechnej. Dzięki TWP także prości ludzie mieli szansę wysłuchać popularyzatorskich, ale wartościowych i interesujących wykładów profesorów wyższych uczelni, podróżników, sławnych postaci, a młodzi asystenci, tacy jak ja, mogli dorobić do skromnych pensji prelekcjami w wiejskich klubach, np. opowiadając o dziedziczeniu gospodarstw rolnych czy umowie dożywocia. Lub o pladze alkoholizmu.

Profesor Akademii Medycznej we Wrocławiu, ceniony uczony, zaproponował mojemu Profesorowi wykład i podał jego tytuł: „Lekarz i jego chory”. Profesor przyjął tę propozycję, serdecznie podziękował i spolegliwie wymusił na koledze medyku zmianę tytułu na: „Chory i jego lekarz”.

Kilka tygodni przed śmiercią Profesor zapytał: „Wie pan, kiedy tak naprawdę umieramy?” i nie czekając na moją reakcję, odpowiedział: „Kiedy przestaje o nas pamiętać ostatnia kobieta..."

$$
* * *
$$

Jeszcze ostatniego dnia pielęgniarka przyniosła stojak, na którym zawieszona była butelka z osoczem krwi, i będącemu już prawie w letargu Profesorowi zaczęła je dożylnie podawać. Profesor zbudził się, wyszarpnął igłę, prawie krzyknął do pielęgniarki: „Proszę to zabrać! To się przyda rodzącym i małym dzieciom. Tego nie wolno marnować!"

$$
* * *
$$

Przed człowiekiem znającym kilka rodzajów średniowiecznej łaciny bezskutecznie próbowano ukryć śmiertelny werdykt.

Martwił się jedynie o żonę. Kiedyś, już z trudem przełykając ślinę, powiedział: „Ja jej w ogóle na to nie przygotowałem...” Choć bywały i takie dni, że ze swojego umierania żartował. ,To jeden z najlepszych raków, panie Jacku, rak płuc najmniej boli!" 
W dniu, w którym umarł, poprosił o papierosa. Znajomy lekarz odpowiedział, że nie wolno palić na szpitalnej sali. Dał jednak Profesorowi marlboro, gdy usłyszał: „Był taki stary zwyczaj, że spełnia się wolę skazańca wstępującego na szafot..."

Godzinę później umarł.

\section{Why is it so bad, if it is so good... Critical analysis of the Polish Organ Transplant Act}

\section{Summary}

Despite the Polish Organ Transplant Act is considered very advanced, the number of organs sourced from deceased donors in Poland is highly insufficient. We believe that this could be improved by modifying the existing Act. In this paper we present our findings and draft proposals for changes of law.

Keywords: organ transplant, sourcing of organs from a deceased donor, insufficient number of organs for ex-mortuo transplantation, shortcomings of the Polish Organ Transplant Act. 